International Research Journal of Management, IT \& Social Sciences
Available online at https://sloap.org/journals/index.php/irjmis/
Vol. 7 No. 6, November 2020, pages: 167-174
ISSN: 2395-7492
https://doi.org/10.21744/irjmis.v7n6.1033

\title{
Leadership and Human Resource Management: Response to the
} COVID-19 Outbreak

\begin{tabular}{lll} 
& O $^{\text {Crosssark }}$ & Sudarmo $^{\text {a }}$ \\
\hline \hline Article history: & Abstract \\
\hline
\end{tabular}

Submitted: 27 September 2020

Revised: 18 October 2020

Accepted: 09 November 2020

\section{Keywords:}

good management;

HR management;

leadership potential; qualitative study;

response COVID-19;
This project reviewed the potential for leadership and human resource management in response to the emergence of the COVID-19 pandemic. In any emergency in a country, the role of a leader with the ability and seriousness of human resource management is believed to be very important. To prove this belief, we have collected many-related literature, such as understanding deeply the aspects of leadership and HR management that have been applied successfully in various international contexts. How this leadership role with good management of HR is effectively applied. Because we conducted this study in the pandemic era, an era where restrictions on public movement are being treated, the method of data collection was through engine searches by relying on keyword utility, for example, "leadership potential", "HR management", "responding to the COVID-19 outbreak", and "qualitative studies". Because this study is categorized, we present the results of the study in the descriptive analysis method under the phenomenological approach. For the findings of this review study to meet the principles of validity and trustworthiness, we, the findings of this study, must be able to answer research questions.

International research journal of management, IT and social sciences (C) 2020. This is an open access article under the CC BY-NC-ND license (https://creativecommons.org/licenses/by-nc-nd/4.0/).

\section{Corresponding author:}

Sudarmo,

Sekolah Tinggi Ilmu Ekonomi Balikpapan, Indonesia.

Email address: sudarmo@stiebalikpapan.ac.id 


\section{Introduction}

Since WHO declared COVID-19 to be a world pandemic outbreak since many affected countries have begun to experience a leadership crisis in response to the attack, observing the trend of the spread of the pandemic that is so fast has made all the leaders of the country move so quickly with various ways of solving this problem (Capano et al., 2020; Putra et al., 2020; Naumann et al., 2020; Adnan \& Anwar, 2020). Many countries are also inseparable from this problem, the spread of the coronavirus from big cities to regional areas. Reflecting on the distribution events that occurred, how a leader plays a role and communicates the crisis to the people and other countries. When a problem is declared, it will undoubtedly have an impact on widening public panic along with the enactment of policies and regulations, both during the emergency period and entering a new average period. In response to this issue, this is what the importance of a leader with his role is required to be able to respond by building a useful communication role to face the COVID-19 crisis and deep concern that requires.

To respond to such critical conditions, it takes a lot of contributive public relations tactics to manage the crisis well. The current general crisis mindset must be replaced, one of which is to allow managers to practice public relations, namely the theory of excellence in public relations. Although the study of excellence does not explicitly address the crisis by PR, much of the literature review and scientific findings apply to developing theory in crisis conditions. To be better, we believe that the role faced by leaders, especially in public relations with human resources which is strategic, has a two-way symmetrical focus, has the authority to act quickly and practitioners with high leadership must be a priority and dominantly responds directly to any disturbances or crises. Suppose the state experiences an emergency that threatens the continuity of the state system (Mitroff et al., 1992; Penrose, 2000), to respond to it. In that case, it must combine crisis communication into a more strategic framework. Some researchers categorize this function as crisis management. For example, Pearson \& Clair (1998), define it as a systematic effort to avoid organizational crises or crises of vigour or to manage problems that occur. To achieve these conditions, organizations or countries must implement a crisis management plan that consists of thought processes and steps to anticipate the complex nature of the crisis (Caywood \& Stocker, 1993; Carlson, 1999; Markóczy, 2001). This includes the appointment of a crisis team, a communication process, a stakeholder assessment, media relations initiatives, and a post-crisis evaluation.

All of these are grouped into the role of leadership in the context of HR management (Hu \& Wang, 2014; Jain, 2016). Meanwhile, leadership in play is about coping with change, setting direction, aligning people, motivating and inspiring - keeping people moving in the right direction, although the main barriers to change often arise when linked to human needs, values, and emotions (Kotter, 1982; Wood, 2002; Wood \& Bandura, 1989). For organizations, statehood, leadership is often considered the most critical factor in determining overall success or failure (Bass, 1999; Hifza et al., 2020; Hutagaluh et al., 2020; Hifza et al., 2020; Hifza, 2020). According to Grunig \& Grunig (1992), excellent leaders provide vision and direction for the organization, creating order out of chaos. So it takes a leadership role that is healthy and high integrity. During the COVID-19 crisis, for example, the leadership of the state became a catalyst for success or a millstone of failure. When understood, the situation is about uncertainty and fear. Leadership is about anticipation, vision, flexibility, and empowerment (Byrd et al., 1987; Sager, 1990). HR management is the ability to manage all resources. Therefore, crisis leadership is the lead manager's ability to provide vision and direction during times of change and uncertainty. Effective leadership during times of crisis is a leader who strengthens the organization's determination to survive and becomes stronger: shaken, but firm and determined to shape the future rather than adapt it (Marshall-Mies et al., 2000; Oliver et al., 2011).

When the country is in shock, the human resource division is an essential key to managing a pandemic which creates various uncertainties, especially health and its impact on the economic sector and people's welfare. At that time, the state depends on human resources to help sustain activities, policies, and calm people's anxiety during prolonged work from home conditions. The rapid spread of the pandemic and the implementation of government policies have caused many economic activities and the public to feel overwhelmed to adapt. So the more parties feel the hardships and hardships so that the economic recession. Here is where leadership with reliable HR is needed who plays a role in leading the continuation of state activities, especially in creating a conducive situation for the wider community. Administration with dedicated HR is expected to be able to scan the dynamics of change to mitigate risks and ensure the safety and public welfare of the entire nation (Kahn, 2020; Lerner \& Berg, 2015; Mansley et al., 2011).

The benefits of this research on leadership and HR management can be divided into two parts; Academically, this study must make a scientific contribution to the study of leadership activities both in the state and in organizations that involve leadership and human resource management functions for the broader community in a country and regional areas. Leadership studies during the COVId-19 crisis in Indonesia were utterly different from other countries, although 
the causes were the same. However, handling and response are certainly very different. In other words, a good leader will be able to increase the productivity of his people by building trust in the community he leads and being able to create a positive and conducive governance environment for continued productivity. For example, when the government makes a solid work spirit, this can help increase retention, increase the job satisfaction of subordinates throughout the government, and can have a positive impact on the benefits of all its people when the issue of COVID19 is a common concern. Therefore, it is hoped that this leadership research can build new relationships with the relationship between government and society as the latest contemporary phenomena when responding to the pandemic together.

From a practical point of perspective, the study on leadership and HR management will benefit from a review analysis of ten international publication journals that are presented to the public and not only to researchers of leading science and policymaking. The issue of leadership in responding to COVID in Indonesia has become a common concern, so studies and analysis from various points of view must be of real benefit both nationally and internationally. This leadership study on the COVID-19 issue should provide the public, policymakers with reading material and discussion that can provide information about the development of response patterns and human resources in Indonesia. For educational benefit, there is a statement by the researcher that there are many studies on leadership in Indonesia. It is explicitly stated that both central and regional governments, as policymakers and the general public will benefit from more reading material on issues of leadership and management in response to the COVID-19 crisis which is currently still an important issue because the impact of this pandemic is comprehensive and massive for sharing sectors of life and the national economy. Therefore, we can formulate the research question; How important is HR leadership and management in responding to the COVID-19 pandemic in Indonesia?

\section{Materials and Methods}

The core objective of this research was that we want to examine the importance of leadership and human resource management factors in responding to the COVID-19 pandemic in Indonesia. To understand and be able to answer the questions of this study, for the first time, we conducted a practical reading of the literature on issues of leadership and human resource management in responding to the COVID-19 in Indonesia, which is still an important issue. After data collection, we then carried out an analysis that involved coding and an in-depth understanding of ten international publications; how the countries that have successfully responded to COVID-19. How is the role of leadership and HR management in response to the pandemic? Because we carried out this study during the implementation of piracy working at home, our data collection method relied on search engines with the help of keywords, including; "leadership role," "human resource management", "COVID-19 response", "qualitative study" We report all data in a qualitative design under the phenomenology approach. In the review process, we found that we answered the study questions by adhering to the principles of high validity and trustworthiness (Morrow, 2005).

\section{Results and Discussions}

In this results section, we present the results of a review of ten international publications that have successfully reported the functions of government leadership and human resources in responding to the emergence and spread of COVID19 in their respective countries.

Gong et al. (2020), noted that the emergence of the COVID-19, which was marked by a new type of virus called Coronavirus 2019, has spread rapidly since the end of 2019 in Wuhan, the capital of central China's Hubei Province. Because of the virus transmitted through the human-to-human respiratory system, the Chinese government has used its leadership potential to manage the emergency time. Early efforts in managing case by case identify and isolate people so that suspected cases control the source of infection and cut off the path of spread. The response and dedication of the government with high leadership has succeeded in handling this pandemic very effectively.

Jernigan (2020), wrote at the start of the spread of fourteen diagnosed cases of COVID-19 in the United States, through US government health agencies and public health partners, spontaneously implemented aggressive measures to slow down and try to stop efforts to contain the spread of COVID-19 within the country. They understand is that the COVID-19 outbreak of coronavirus disease originated in China and spread to other countries and territories. So with the existing cases, they are sinning quickly among repatriated persons from high-risk settings, the government

Sudarmo, S. (2020). Leadership and human resource management: response to the COVID-19 outbreak. International Research Journal of Management, IT and Social Sciences, 7(6), 167-174.

https://doi.org/10.21744/irjmis.v7n6.1033 
with good leadership with public health partners are implementing aggressive testing to slow and contain transmission of the pandemic in the country while closing all national borders to ensure a break in the chain of virus spread.

La et al. (2020), stated that having geographic relations and proximity to China, Vietnam is the country that recorded the first Coronavirus outbreak to experience the transmission of COVID-19). However, with the country's good management leadership, it is estimated that Vietnam does not have a high risk of infectious compared to the prevention efforts in most other countries around the world. The Vietnamese leader's response was swift and effective in protecting the interests of its citizens. This paper proves that while Vietnam is under-resourced, the government has shown high leadership and political readiness to stop the pandemic that has emerged since the early days of its neighbors. With Human Resources Management through timely communication about the development of an outbreak from the government and the media, combined with the most audited scientific studies of the new virus by the Vietnamese scientific community, all have proven Vietnamese human resources with reliable information work systems.

Kwok et al. (2020), studied the behavior of random social media users to prevent COVID-19 infection and investigated the behavior of participants who were asked to become study participants. How do they respond to the spread of the coronavirus disease? This study found that participants had a low perception of vulnerability and a high perception of severity. There are significant differences in vulnerability between different age groups, places of residence, and education levels and between people with congenital diseases and those without experience. Significantly differences in self-education were found between urban and rural people. Residents between the ages of 38 and 55 indicated that they felt safer staying at home to avoid infection. Their study concluded that the final wave of preventive health education needs to be trained according to the group, age, city of origin, and level of education.

Campos et al. (2020), noted that COVID-19 has the potential to attack all humans, despite different backgrounds. In this regard, studies identifying the specificities of each country are very primary in minimizing the impact caused by this COVID-19 disease. Therefore the aim of their research is to the evaluation of potential exposure in 853 cities in Brazil's second-most populous state. They studied to direct government policies to control public interests not being exposed to the pandemic. Then, they conducted epidemiological studies based on multi-criteria decision studies, and they used multiple-aspect measures. The essence of their project is how the management of the country's leadership responds quickly to every COVID-19 case and reduces it as fast as possible.

Cheng et al. (2020), noted the Taiwanese government by the Center for Disease Control since late December has detected news of the unknown COVID-19 outbreak in Wuhan, China, from social media. One week later, the Chinese government announced the pathogen was a new coronavirus, officially named the coronavirus- 2 severe acute respiratory syndrome (SARS-CoV-2). Then February 2020, the spread of Chinese coronavirus cases reached 80,000, with around 2,800 deaths. The outbreak has hit 60 countries around the world, with more than 6,000 cases and 106 deaths, just two months after the virus was discovered. Only the first two cases of COVID-19 in Taiwan were detected on January 21. When the outbreak hit Taiwan, the Taiwan leadership immediately adopted a three-pillar strategy: surveillance with rapid risk assessment, border closure and quarantine, and construction of medical laboratories. In fact, before the outbreak, Taiwan had established a strict surveillance system that included laboratory surveillance and social media. After the outbreak was detected by social media surveillance, the Taiwan surveillance team continued to compile virus news from social media, government reports, and official press releases to monitor progress in China daily and periodically update rapid risk assessments to the provincial level for preventive decision making.

Zhang et al. (2020), stated since the COVID-19 was confirmed by WHO originating in Wuhan, Chinese anesthetists have faced an increase in infected patients since December 2019. According to reports, the main route of transmission is through breathing and close contact. Anesthesia providers are at high risk when responding to an alarming mass emergency. Then, the Chinese government with good leadership immediately took action but was not limited to national action and educating citizens online regarding special procedures for the management of infection control cases, oxygen therapy, support for improved ventilation, hemodynamic management, and analgesia. As the pandemic situation has been going on for quite a while, special platforms have also been used for free mental care of the many anesthesia providers participating in critical and care for COVID-19 patients. Finally, this paper documents the swift action, lessons learned for all citizens, and the future preparations needed by residents especially those who are infected.

Adalja et al. (2020), examined how the US Department of Health prepares and priorities in responding to COVID19. At the end of 2019, a cluster of unexplained cases of COVID-19 of viral pneumonia occurred in China. This earliest cluster of patients with what later became known as c COVID-19 heralded the arrival of a new pandemic caused by a novel coronavirus, severe acute respiratory syndrome coronavirus 2 . Despite the difficulties caused by this pandemic, it is clear that COVID-19 is a new and deadly pandemic. Overcoming this infectious issue, appropriate and prompt 
actions taken to prepare and prioritize the United States' Department of care and health against COVID-19 with the main aim of stopping the spread of COVID-19 through public health interventions throughout the country.

Cheng et al. (2020), examine how governments respond to the COVID-19 event dataset around the world. How the country's leaders have made policies in response to the spread of COVID-19. The public policy started with big data in more than 195 countries. This study succeeded in documenting state policies, including the type of national versus regional enforcement policies in China. The specific public and territorial groups that the policy focuses on, and the time frame in which each policy is implemented. Then this study further analyzes the policies established using the Bayesian measurement model, which shows the rapid acceleration of the implementation of key policies across the country from mid-March 2020. They firmly believe that this data will be important for policymakers in their next fight against the pandemic. Several different effective policies in dealing with the spread of COVID-19.

Koirala et al. (2020), examine the government's readiness and response to the COVID-19 pandemic disaster in Nepal. It is a case study of the COVID-19 outbreak originating from Wuhan, which has isolated millions of people from business activities and routines. Even though the spread of the pandemic is severe, it is almost impossible for the government to stop it. With the readiness of the government, business people, and state partners, finally, they can understand the preparedness and respond to responses to critical situations. The core objective is to understand the overall management situation of the Nepalese government based on experiences from other countries post COVID-19. With this study, they have described how the leadership of clinical expertise, professional jobs to identify needs and gaps and make recommendations for cooperative government preparation and response. With China's experience in controlling the COVID-19 situation since the SARS outbreak, it is currently not too risky for Nepal to create a megascale surveillance system to detect and follow up on infected people.

The main objective of this research is to find answers to research questions; how crucial leadership and human resource management are in responding to the COVID-19 pandemic. With field evidence from a variety of information from the ten international papers that we studied, it said that the above findings are very valid because they have answered research questions. In general, the ten international publications above which have proven the human resource management and leadership of each country we studied, have played a full and maximum role in the effort to respond to the emergence of the pandemic. These findings also prove that the response does not only come from state leaders, but there are still many government agencies and partners such as the health office and health agencies that have also played an active and full role, starting from identification to fighting the spread of Virus. The study of Hale et al. (2020), for example, which has varied government responses to COVID-19, has supported our research with evidence of government work in Blavatnik.

Alon et al. (2020), suggested that this study is not specific to the response of developed or developing countries, but by searching online data based on Google Scholar, we found that the cross-country response to COVID-19 has various approaches and frameworks by the government in dealing with the coronavirus outbreak which has affected their lives state and government. Although our findings have made an extensive understanding of the nature of individual countries' responses to the coronavirus outbreak, these findings are primary findings that provide insight into more than just handling pandemic in developed countries. This finding also informs only in developed countries that national representatives respond to each case quickly (Ong et al., 2020; Shokrani et al., 2020). They generally understand the dangers and risks of the Coronavirus outbreak affecting every citizen in many parts of the world.

Oh et al. (2020), understand how the national response by the Republic of South Korea to COVID-19 and how this becomes a lesson for other countries. The excellence of management and the health reform system in this country has convinced us that each nation has responded to COVID-19 in different ways and capacities. Most of our employees are from China, Taiwan, Japan, and South Korea. They are like what we have found that it is true that the leadership and human resource management system of this country should be a role model for many other countries, mainly underdeveloped countries.

\section{Conclusion}

In this final section, we summarize the findings of our study entitled "Leadership and Human Resource Management: Responses to the COVID-19 Outbreak". In general, of the ten international publications that we studied, they have shown a high commitment to responding to the threat of COVID-19 to the country and its citizens. On average, the governments in several countries we have studied are very responsive, starting from identifying, treating, and treating each new case that is supported by the addition of health facilities and funding. The point is that the leadership and

Sudarmo, S. (2020). Leadership and human resource management: response to the COVID-19 outbreak. International Research Journal of Management, IT and Social Sciences, 7(6), 167-174.

https://doi.org/10.21744/irjmis.v7n6.1033 
management of human resources in each country that we studied have been running optimally, especially in several developed countries such as China, South Korea, the US, and several European countries.

Conflict of interest statement

The author declared that he has no competing interests.

Statement of authorship

The author has a responsibility for the conception and design of the study. The author has approved the final article.

Acknowledgments

I am grateful to two anonymous reviewers for their valuable comments on the earlier version of this paper. 


\section{References}

Adalja, A. A., Toner, E., \& Inglesby, T. V. (2020). Priorities for the US health community responding to COVID19. Jama, 323(14), 1343-1344.

Adnan, M., \& Anwar, K. (2020). Online Learning amid the COVID-19 Pandemic: Students' Perspectives. Online Submission, 2(1), 45-51.

Alon, T. M., Kim, M., Lagakos, D., \& VanVuren, M. (2020). How Should Policy Responses to the COVID-19 Pandemic Differ in the Developing World? (No. w27273). National Bureau of Economic Research.

Bass, B. M. (1999). Two decades of research and development in transformational leadership. European journal of work and organizational psychology, 8(1), 9-32.

Byrd, R. J., Calzolari, N., Chodorow, M., Klavans, J. L., Neff, M. S., \& Rizk, O. A. (1987). Tools and methods for computational linguistics. Computational Linguistics, 13, 219-240.

Campos, I. S., Aratani, V. F., Cabral, K. B., Limongi, J. E., \& de Oliveira, S. V. (2020). A vulnerability analysis for the management of and response to the COVID-19 epidemic in the second most populous state in Brazil. medRxiv.

Capano, G., Howlett, M., Jarvis, D. S., Ramesh, M., \& Goyal, N. (2020). Mobilizing policy (in) capacity to fight COVID-19: Understanding variations in state responses. Policy and Society, 39(3), 285-308.

Carlson, J. (1999). Critical incident management in the ultimate crisis. FBI L. Enforcement Bull., 68, 19.

Caywood, C., \& Stocker, K. P. (1993). The ultimate crisis plan. Crisis response, 409-427.

Cheng, C., Barceló, J., Hartnett, A. S., Kubinec, R., \& Messerschmidt, L. (2020). Covid-19 government response event dataset (coronanet v. 1.0). Nature human behaviour, 4(7), 756-768.

Gong, F., Xiong, Y., Xiao, J., Lin, L., Liu, X., Wang, D., \& Li, X. (2020). China's local governments are combating COVID-19 with unprecedented responses-from a Wenzhou governance perspective. Frontiers of Medicine, 1-5.

Grunig, J. E., \& Grunig, L. A. (1992). Models of public relations and communication. Excellence in public relations and communication management, 1992, 285-325.

Hale, T., Petherick, A., Phillips, T., \& Webster, S. (2020). Variation in government responses to COVID-19. Blavatnik school of government working paper, 31 .

Hifza, A. (2020). The Model of Competitive Advantage Development in Private Islamic Education Institutions. In BASA 2019: Proceedings of the Third International Seminar on Recent Language, Literature, and Local Culture Studies, BASA, 20-21 September 2019, Surakarta, Central Java, Indonesia (p. 205). European Alliance for Innovation.

Hifza, H., Suhardi, M., Aslan, A., \& Ekasari, S. (2020). Kepemimpinan Pendidikan Islam Dalam Perspektif Interdisipliner. NidhomulHaq: Jurnal ManajemenPendidikan Islam, 5(1), 46-61.

Hifza, J., Palapa, A., \& Maskur, A. (2020). The Strategic Foundation for Competitive Excellent Development in Integrated Islamic Primary Schools in Indonesia.

Hu, Z., \& Wang, X. T. (2014). Trust or not: Heuristics for making trust-based choices in HR management. Journal of Business Research, 67(8), 1710-1716. https://doi.org/10.1016/j.jbusres.2014.02.017

Hutagaluh, O., Aslan, P. P., \& Mulyono, A. W. S. S. (2020). Situational Leadership On Islamic Education. IJGIE (International Journal of Graduate of Islamic Education), 1(1), 1-7.

Jain, A. (2016). Shift in HR professionals role: critical trends in HR management practices. International research journal of management, IT and social sciences, 3(5), 38-47.

Jernigan, D. B. (2020). Update: public health response to the coronavirus disease 2019 outbreak-United States, February 24, 2020. MMWR. Morbidity and mortality weekly report, 69.

Kahn, L. H. (2020). Who's In charge? Leadership during epidemics, bioterror attacks, and other public health crises. ABC-CLIO.

Koirala, J., Acharya, S., Neupane, M., Phuyal, M., Rijal, N., \& Khanal, U. (2020). Government preparedness and response for 2020 pandemic disaster in Nepal: a case study of COVID-19. Available at SSRN 3564214.

Kotter, J. P. (1982). What effective general managers really do. Harvard business review, 60(6), 156-167.

Kwok, K. O., Li, K. K., Chan, H. H., Yi, Y. Y., Tang, A., Wei, W. I., \& Wong, S. Y. (2020). Community responses during early phase of covid-19 epidemic, Hong Kong. Emerg Infect Dis, 26(7), 10-3201.

La, V. P., Pham, T. H., \& Ho, M. T. (2020). P Nguyen, KL; Vuong, TT; Vuong, QH Policy response, social media and science journalism for the sustainability of the public health system amid the COVID-19 outbreak: The Vietnam lessons. Sustainability, 12, 2931.

Lerner, H., \& Berg, C. (2015). The concept of health in One Health and some practical implications for research and education: what is One Health?. Infection ecology \& epidemiology, 5(1), 25300.

Sudarmo, S. (2020). Leadership and human resource management: response to the COVID-19 outbreak. International Research Journal of Management, IT and Social Sciences, 7(6), 167-174.

https://doi.org/10.21744/irjmis.v7n6.1033 
Mansley, L. M., Donaldson, A. I., Thrusfield, M. V., \& Honhold, N. (2011). Destructive tension: mathematics versus experience - the progress and control of the 2001 foot and mouth disease epidemic in Great Britain. Revue Scientifique et Technique-OIE, 30(2), 483.

Markoczy, L. (2001). Consensus formation during strategic change. Strategic Management Journal, 22(11), 10131031.

Marshall-Mies, J. C., Fleishman, E. A., Martin, J. A., Zaccaro, S. J., Baughman, W. A., \& McGee, M. L. (2000). Development and evaluation of cognitive and metacognitive measures for predicting leadership potential. The Leadership Quarterly, 11(1), 135-153. https://doi.org/10.1016/S1048-9843(99)00046-6

Mitroff, I. I., Pearson, C., \& Pauchant, T. C. (1992). Crisis management and strategic management: similarities, differences and challenges. Advances in strategic management, 8(2), 235-260.

Morrow, S. L. (2005). Quality and trustworthiness in qualitative research in counseling psychology. Journal of counseling psychology, 52(2), 250.

Naumann, E., Möhring, K., Reifenscheid, M., Wenz, A., Rettig, T., Lehrer, R., ... \& Cornesse, C. (2020). COVID-19 policies in Germany and their social, political, and psychological consequences. European Policy Analysis.

Oh, J., \& Klivans, L. (2020). How The Novel Coronavirus Hijacks Our Defenses. Retrieved May 24, 2020.

Oliver, P. H., Gottfried, A. W., Guerin, D. W., Gottfried, A. E., Reichard, R. J., \& Riggio, R. E. (2011). Adolescent family environmental antecedents to transformational leadership potential: A longitudinal mediational analysis. The Leadership Quarterly, 22(3), 535-544. https://doi.org/10.1016/j.leaqua.2011.04.010

Ong, E. Z., Chan, Y. F. Z., Leong, W. Y., Lee, N. M. Y., Kalimuddin, S., Mohideen, S. M. H., ... \& Low, J. G. H. (2020). A dynamic immune response shapes COVID-19 progression. Cell host \& microbe. https://doi.org/10.1016/j.chom.2020.03.021

Pearson, C. M., \& Clair, J. A. (1998). Reframing crisis management. Academy of management review, 23(1), 59-76.

Penrose, J. M. (2000). The role of perception in crisis planning. Public Relations Review, 26(2), $155-171$. https://doi.org/10.1016/S0363-8111(00)00038-2

Putra, P., Liriwati, F. Y., Tahrim, T., Syafrudin, S., \& Aslan, A. (2020). The Students Learning from Home Experiences during Covid-19 School Closures Policy In Indonesia. Jurnal Iqra': Kajian Ilmu Pendidikan, 5(2), 30-42.

Sager, J. C. (1990). Practical course in terminology processing. John Benjamins Publishing.

Shokrani, A., Loukaides, E. G., Elias, E., \& Lunt, A. J. (2020). Exploration of alternative supply chains and distributed manufacturing in response to COVID-19; a case study of medical face shields. Materials \& design, $192,108749$. https://doi.org/10.1016/j.matdes.2020.108749

Wood, M. (2002). Ecotourism: Principles, practices and policies for sustainability. UNEP.

Wood, R., \& Bandura, A. (1989). Social cognitive theory of organizational management. Academy of management Review, 14(3), 361-384.

Zhang, H. F., Bo, L., Lin, Y., Li, F. X., Sun, S., Lin, H. B., ... \& Meng, L. (2020). Response of Chinese anesthesiologists to the COVID-19 outbreak. Anesthesiology: The Journal of the American Society of Anesthesiologists, 132(6), 1333-1338. 